\title{
The pathogenecity of H5N1 highly pathogenic Avian Influenza (HPAI) virus clade 2.3.2. in Indonesian indigenous chicken by contact tranmission with infected duck
}

\author{
R. Damayanti, A.Wiyono, H. Nuradji and M. I. Cahyono \\ Indonesian Research Center for Veterinary Science, Bogor 16114 - Indonesia \\ Corresponding E-mail: harimurti.nuradji@gmail.com
}

Received September 23, 2016; Accepted November 18, 2016

\begin{abstract}
ABSTRAK
Penelitian penularan buatan dilakukan pada sembilan ekor ayam kampung sehat yang dipelihara bersama dengan dua ekor itik umur 30 hari yang diinfeksi secara buatan dengan virus H5N1 HPAI clade 2.3.2 pada fasilitas Biosafety Laboratory Level 3 (BSL-3). Tujuan penelitian adalah untuk mengetahui patogenitas virus H5N1 HPAI clade 2.3.2 pada ayam kampung. Hasil penelitian menunjukkan bahwa ayam kampung dalam waktu 24 jam menunjukkan gejala klinis ringan seperti bulu berdiri dan lemah dan setelah 48 jam kesembilan ayam mati, sedangkan kedua itik tetap hidup dengan gejala klinis sangat berat. Virus HPAI H5N1 berhasil diisolasi dari preparat usap (swab) yang berasal dari ayam dan itik tersebut, menandakan bahwa mereka terinfeksi virus tersebut. Secara mikroskopik, ayam kampung menunjukkan ensefalitis, trakheitis, miokarditis, pneumonia interstitialis, hepatitis, proventrikulitis, enteritis, pankreatitis, nefritis dan bursitis yang kesemuanya bersifat peradangan non-supuratif. Lesi dominan lainnya yaitu nekrosis pada limpa dan pankreas. Virus H5N1 HPAI clade 2.3.2 dideteksi dengan metode imunohistokimia dan ditemukan pada hampir semua organ visceral yang terserang. Hasil ini menunjukkan bahwa ayam kampung asal Indonesia tergolong peka terhadap infeksi virus HPAI H5N1 clade 2.3.2 dan virus tersebut dapat ditransmisikan dengan mudah melalui penularan kontak dari itik yang terinfeksi ke ayam kampung.
\end{abstract}

Kata kunci: Patogenitas, virus H5N1 HPAI clade 2.3.2, ayam kampung

\begin{abstract}
An experimental transmission study was conducted using nine healthy Indonesian indigenous chickens placed together with two 30 days old ducks which were experimentally infected with H5N1 HPAI clade 2.3.2 virus in the Biosafety Laboratory Level 3 (BSL-3) facilities. The aim of the study was to find out the pathogenicity of H5N1 HPAI virus clade 2.3.2 in Indonesian indigenous chickens. The study showed that within twenty four hours rearing, the chickens were exhibited mild clinical signs and by 48 hours, all of the chickens died, whereas the ducks survived but with severe clinical signs. The H5N1 HPAI virus has been successfully isolated from chickens and ducks swabs, confirming that those animals were infected by the virus. Histologically, the infected chicken encountered with severe inflammation reaction namely non suppuratives encephalitis, tracheitis, myocarditis, interstitial pneumonia, hepatitis, proventriculitis, enteritis, pancreatitis, nephritis and bursitis. Necrotizing spleen and pancreas were also prominent. Viral antigen was detected by immunohistochemistry staining in various affected visceral organs. This suggests that Indonesian indigenous chickens were susceptible to H5N1 HPAI virus clade 2.3.2 and it can be transmitted easily to Indonesian indigenous chickens by contact transmission with infected ducks.
\end{abstract}

Keywords: Pathogenicity, H5N1 HPAI virus clade 2.3.2, Indonesian indigenous chickens 


\section{INTRODUCTION}

Highly Pathogenic Avian Influenza (HPAI) H5N1 was firstly reported in 1996 in Guangdong Province, China (Xu et al., 1999). This disease has spread widely around the world, and caused significant impact in affected countries (Webster and Govorkova, 2006), including in Indonesia (Wiyono et al., 2004). The virus of H5N1 HPAI is very contagious in poultry and generates high mortality up to $100 \%$ (Swayne and Halvorson, 2008). Aetiological agent of HPAI belongs to orthomyxoviridae family and genus of influenza A virus (The International Committee on Taxonomy of Viruses 2012). Genus of influenza A virus have broad host species, from animals to human (Swayne and Halvorson 2008). Based on its surface glycoproteins: hemmaglutinin (HA) and neuraminidase (NA), influenza virus classified into 18 hemaglutinin subtypes (H1-18) and 11 neuraminidase subtypes (N1-11) had been recognized (Tong et al., 2012; 2013). H5N1 HPAI virus infected systematically and produced damaged in cardiovascular, nervous system (Swayne and Halvorson 2008), integument and skeleton (Swayne and Pantin-Jackwood, 2008). Inflammation and necrosis in various visceral organs were detected (Swayne and PantinJackwood, 2008).

In Indonesia, HPAI cases were first reported in the end of 2003 affecting not only commercial poultry farms but also Indonesian indegenous chicken (Wiyono et al., 2004). This viruses were majority affecting chicken in Indonesia (Wiyono et al., 2004). However, in late 2012, there were outbreaks causing high mortality in ducks in three provinces i.e. Central and East Java and Yogyakarta, and further characterization showed that these outbreaks caused by a new clade 2.3.2 virus (Wibawa, et al., 2012; Dharmayanti et al., 2013). Since it has been reported to be isolated from dead migratory birds in Qinghai Lake region, China in 2009 (Hu et al., 2011; Zhao et al., 2012) H5N1 HPAI virus clade 2.3.2 has been reported to circulate in several countries not only affecting wild birds (including ducks) but also chicken (Kang et al., 2011; Reid et al., 2011; Marinova-Petkova et al., 2012; Nagarajan et al., 2012; Nemeth et al., 2013).

In Indonesia, even though clade 2.3.2 has been reported to cause high mortality in domestic ducks, there was limited information on the possibility of infected duck to spread the disease to chickens, and the pathogenicity mechanism of this virus in chickens, particularly in Indonesian indigenous chicken. In natural cases, sub-clinical or less severe infection of H5N1 HPAI is sometimes reported to occur in Indonesian indigenous chicken. Hypothetically, this phenomenon is probably due to the resistance of chicken to the disease (Sartika et al., 2011). In order to reveal the circumstances, the study was aimed to find out the pathogenicity of the new clade 2.3.2 in Indonesian indigenous chickens.

\section{MATERIALS AND METHODS}

\section{H5N1 HPAI virus strain}

The H5N1 HPAI virus used in this study was A/duck/Sukoharjo/BBVW-1428-9/2012

belonging to clade 2.3.2 (Wibawa et al., 2012). Virus was isolated from duck in Central Java Province, Indonesia (Wibawa et al., 2012).

\section{Experimental Animals}

The use of materials in this study has been approved by Animal Ethics Committee for Using Animal and Scientific Procedures in Indonesian Research Center for Veterinary Science, Bogor. Nine birds of 20 weeks old Indonesian indigenous chickens (Gallus-gallus bankiva) and 30 days old of two Alabio ducks (Anas platyrhinchos), which were clinically healthy were used in this study. The chickens and ducks were obtained from a farm in Bogor, West Java, Indonesia. Chickens and ducks were housed in isolation unit (Montair Andersen B.V. HM 1500, Sevenum, The Netherlands) which were ventilated with HEPAfiltered air, and equipped with continuous lighting. Commercial pellets and water were provided ad libitum. Numbered leg bands were used to identify the birds individually.

\section{Experimental Transmission}

Two ducks were inoculated by intra-nasal, oral and ocular routes with a total of $0.2 \mathrm{~mL}$ of diluted infective allantoic fluid containing a total of $10^{6.8} \mathrm{ELD}_{50}$. Three days after ducks being inoculated and exhibited clinical signs, nine Indonesian indigenous chickens were placed in the same isolator unit as the ducks. Chickens and ducks were monitored daily for clinical signs and mortalities.

\section{Samples Collection}

Oropharyngeal and cloacal swabs were collected using sterile cotton swabs prior to 
challenge, at 48 hours and 3 days post-challenge for chickens and ducks. They were put in a tube of transport medium containing MEM medium, 2\% fetal calf sera (FCS) and antibiotics. These were stored at $-70^{\circ} \mathrm{C}$ before subjected to virus isolation. Blood samples were collected from brachial veins of each chicken and duck prior to challenge according to animal welfare standard for serological test. Tissue samples of brain, trachea, lung, liver, heart, skeletal muscle, intestine, kidney and spleen from chickens and ducks that euthanized or died were collected for histopathological examination .

\section{Virus Isolation in Embryonated Chicken Eggs (ECE's)}

Virus isolation in embryonated chicken egg Specific Pathogen Free (SPF) and Specific Antibody Negative (SAN) was conducted according to World Organization for Animal Health (OIE, 2012). Briefly, $0.2 \mathrm{~mL}$ sample was inoculated into allantoic fluid of 9-11 days old eggs. Inoculated eggs were incubated at $37^{\circ} \mathrm{C}$ for 5 days. Survived, dying and dead eggs were stored at $4^{\circ} \mathrm{C}$ for at least 12 hours. The eggs allantoic fluids were tested with rapid agglutination test (HA) by adding $25 \mu \mathrm{L}$ of $10 \%$ chicken red blood cells (RBC) into $25 \mu \mathrm{L}$ of allantoic fluids. Allantoic fluids were declared as positive if there is agglutination.

\section{Serological Test}

Serum samples were tested using Hemaglutination test followed the procedure from World Organization for Animal Health (OIE) with minor modification (OIE, 2012) to determine the antibody titer of the chickens and ducks vefore experiment. Formaldehide-inactivated antigen generated from A/duck/Sukoharjo/BBVW-14289/2012 virus was used in this test. HI titer were reported as $\log 2$ titers. Briefly, sera were inactivated at $56^{0} \mathrm{C}$ for 30 minutes. Sera were treated with $0.5 \%$ chicken red blood cells (RBC) to remove nonspecific reaction. Sera were tested with $\mathrm{HI}$ test by using $\mathrm{AI}$ antigen and $0.5 \% \mathrm{RBC}$.

\section{Post-mortum Examination}

The birds dying were sacrificed according to the animal welfare standard. Sacrificed birds were necropsied and examined for gross pathological lesions. Several organs were sampled, processed and stained with Hematoxillin and eosin (H\&E) using standard method (Drury and Wallington, 1980). The descriptive lesions were scored according to the degree of severity for each organ. No specific lesion (NSL) or mild, moderate and severe lesions were marked as,+++ and +++ respectively.

\section{Immunohistochemistry Assay}

Immunohistochemistry was conducted according to Damayanti et al. (2004a) to detect the viral antigens. The slides were treated with proteolytic enzyme to unmask the aldehyde linkage (Shi and Taylor 2013). Briefly, slides were added with primary antisera, followed by $3 \%$ hydrogen peroxides, biotinylated secondary antibody (DAKO, Denmark) and avidin biotin peroxsidase (DAKO). Visualization of the antigen was achieved by adding with substrate called 3-3Diamino benzidine (DAB) (DAKO, Denmark). Samples were determined as positive if viral antigens were detected as brown color and microscopically ( 10x20 magnification/field) was scored as - if there was no antigen at all, few (1-5 antigens/cell), moderate (6-10 antigens/cell) and huge (more than 10 antigens/cell).

\section{Data Analysis}

Data from serological test, virus isolation, clinical signs, post-mortum examination, and immunohistochemistry assay were analysed descriptively.

\section{RESULTS AND DISCUSSIONS}

As indicated in Table 1, prior to infection, chickens and ducks were clinically healthy and their sera were negative after tested by HI assay and all swabs tested were negative by virus isolation in eggs. This indicates that chickens and ducks were not previously exposed with H5N1 HPAI. After infection, HI test shows that all the chickens and ducks were serologically negative for influenza A virus subtype $\mathrm{H} 5$ prior to challenge as shown in Tabel 1. These features were also reported by Wibawa et al. (2013).

In acute stage the chickens developed severe clinical sign and succumbed to death within 48 hours post infection (Figure 1). This is in accordance with previous study where H5N1 HPAI clade 2.3.2 isolated from healthy mallard was highly pathogenic in chickens generating mortality in all chickens within 24 hours post infection (Kim et al., 2011). In this study the chickens were dead faster than the ducks that were infected earlier. This means that Indonesian H5N1 HPAI virus clade 2.3.2 was more 
Table 1. Clinical Signs, Serology and Virus Isolation Detected in Ducks and Chickens Before and After Infection.

\begin{tabular}{ccccccccc}
\hline \multirow{2}{*}{ Bird } & \multicolumn{3}{c}{ Before Infection } & & \multicolumn{3}{c}{ After Infection } \\
\cline { 2 - 3 } Species & Clinical signs & Serology & Virus isolation & & Clinical signs & Serology & Virus isolation \\
\hline Ducks & $\begin{array}{c}\text { No clinical } \\
\text { signs }\end{array}$ & negative & negative & & $\begin{array}{c}\text { Clinical signs } \\
\text { observed }\end{array}$ & NT & positive \\
Chickens & $\begin{array}{c}\text { No clinical } \\
\text { signs }\end{array}$ & negative & negative & & $\begin{array}{c}\text { Clinical signs } \\
\text { observed }\end{array}$ & NT & positive \\
\hline
\end{tabular}

NT : not tested

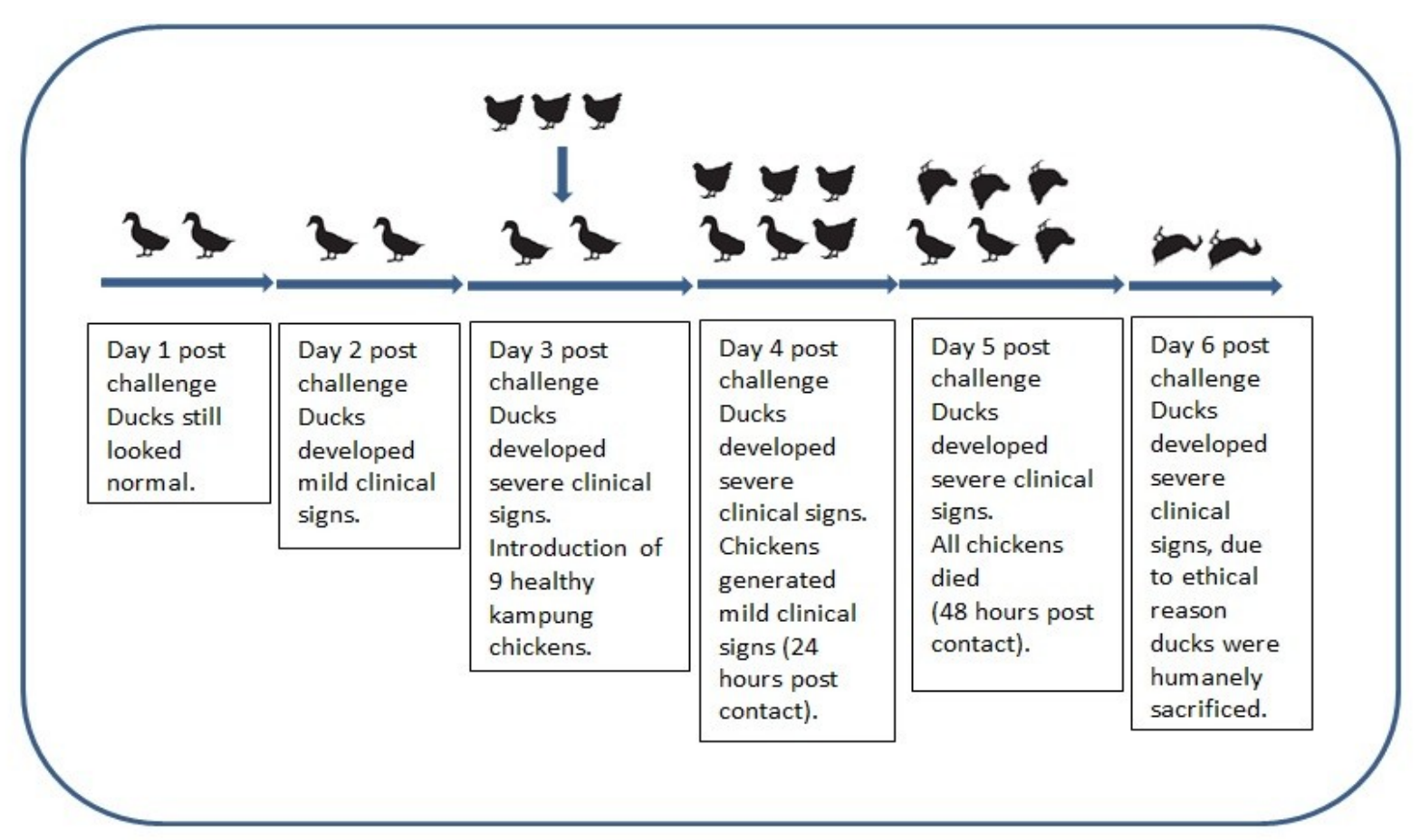

Figure 1. Diagram of the Onset of Present Study

pathogenic in Indonesian indigenous chickens than in ducks and can be transmitted easily from infected ducks particularly when those were in the stage of acute infection (days 3 post infection). According to Swayne and Pantin-Jackwood (2006), HPAI virus was more pathogenic in chickens and other galliforme birds, and usually produces no infection or mild disease in ducks, and that the severity of disease is associated with high virus replication titres in the host. In this case the chicken did not show resistance to the disease (Sartika et al., 2011). This strongly suggests that
Indonesian indigenous chickens should not be managed mingle with duck to minimize the transmission of H5N1 HPAI virus.

The clinical signs were characterized by slight listlessness, ruffled feathers and drowsiness started to be observed 2 days post-challenge in ducks. As seen on Figure 1, on day 3 postchallenge, ducks developed severe clinical signs such as tremors, loss of balance, paralysis and lethargy. This findings were similar to the pathogenicity study reported by Pantin-Jackwood et al. (2013) who stated that domestic ducks play 
an important role in the epidemiology of $\mathrm{H} 5 \mathrm{~N} 1$ infection in Asia, Africa and Eastern Europe.

Table 1 indicated that swabs collected from these ducks and chickens were positive by virus isolation in eggs, suggesting that all the chickens and ducks were infected by H5N1 HPAI virus. The isolation of virus from swabs of ducks and chickens indicates the viral shedding both from infected ducks and in contact chickens. This suggests the potential of ducks and chickens to

Table 2. Degree of Severity in Various Organs of Indonesian Indigenous Chickens Infected by H5N1 Virus Clade 2.3.2.

\begin{tabular}{cccccccccccccccc}
\hline \multirow{2}{*}{$\begin{array}{c}\text { Bird } \\
\text { ID }\end{array}$} & 1 & 2 & 3 & 4 & 5 & 6 & 7 & 8 & 9 & 10 & 11 & 12 & 13 & 14 \\
\hline 1 & ++ & ++ & + & ++ & + & ++ & ++ & + & ++ & +++ & + & +++ & ++ & +++ \\
2 & - & +++ & + & ++ & + & + & ++ & ++ & ++ & ++ & +++ & ++ & ++ & +++ \\
115 & + & + & - & + & - & - & - & +++ & ++ & ++ & ++ & - & ++ & +++ \\
174 & ++ & + & ++ & - & - & - & ++ & ++ & + & +++ & - & ++ & ++ & - \\
181 & ++ & - & - & - & - & - & ++ & - & + & - & +++ & + & +++ & - \\
191 & ++ & + & + & + & - & - & + & +++ & ++ & - & - & - & - & - \\
196 & ++ & - & ++ & + & - & - & + & + & + & ++ & + & - & ++ & ++ \\
\hline
\end{tabular}

1: Brain, 2: Nasal Cavity, 3: Trachea, 4: Feather, 5: Thymus, 6: Heart, 7: Lung, 8: Proventiculus, 9: Liver, 10: Spleen, 11: Intestine, 12: Pancreas, 13: Kidney, 14: Bursa

- : No specific lesion (NSL), + : Mild lesion, ++ : Moderate lesion, +++ : Severe lesion
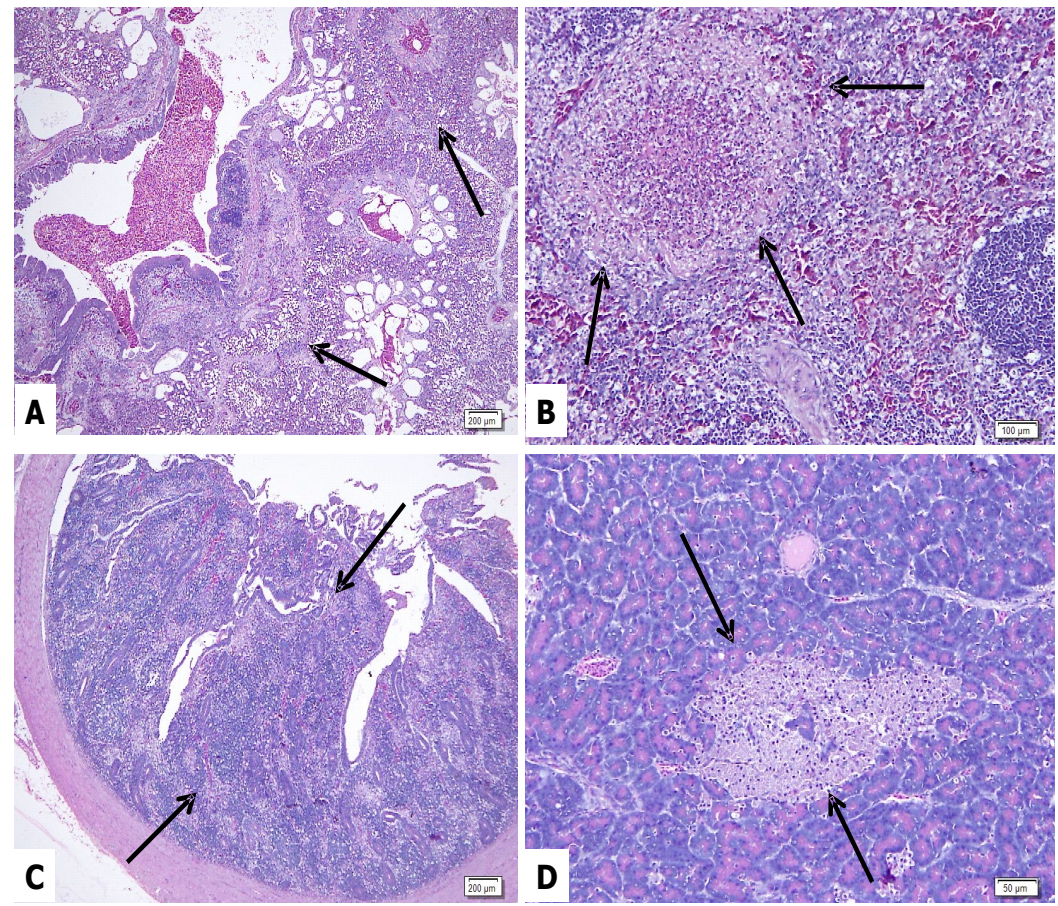

Figure 2. Interstitial Pneumonia of Lung (A); Focal Necrosis of Splenic Red Pulp (B); Enteritis (C) and Focal Necrosis of Pancreatic Islet (D) 
spread H5N1 HPAI virus clade 2.3.2 to the environment. Other study showed that virus was able to be isolated from ducks following infection with clade 2.3.2 (Nemeth et al., 2013).

Table 2 represents the severity degree of lesion in various organs of the chickens affected by $\mathrm{H} 5 \mathrm{~N} 1$ clade 2.3.2. The lesions had marked variation on the distribution and expression of HPAI among the tissues and avian species, as also reported by Costa et al. (2012). Microscopically there were multifocal degeneration to necrosis of the brain, hepatic cells, pancreatic islets, splenic

Table 3. Antigen Detection in Various Organs of Indonesian Indigenous Chickens by Immunohistochemistry

\begin{tabular}{cccccccccccccccc}
\hline \multirow{2}{*}{$\begin{array}{c}\text { Bird } \\
\text { ID }\end{array}$} & 1 & 2 & 3 & 4 & 5 & 6 & 7 & 8 & 9 & 10 & 11 & 12 & 13 & 14 \\
\hline & 1 & 18 & Antigen Detection in Various Visceral Organs \\
2 & +++ & - & + & ++ & + & +++ & +++ & ++ & +++ & +++ & ++ & +++ & +++ & +++ \\
115 & +++ & + & - & +++ & - & - & - & ++ & ++ & +++ & ++ & ++ & +++ & +++ \\
174 & +++ & ++ & ++ & - & - & +++ & +++ & ++ & ++ & +++ & - & +++ & +++ & - \\
181 & ++ & + & + & - & - & ++ & - & - & ++ & - & +++ & ++ & ++ & - \\
191 & +++ & + & + & +++ & - & +++ & ++ & ++ & +++ & +++ & - & +++ & +++ & - \\
196 & +++ & ++ & ++ & +++ & +++ & + & +++ & ++ & ++ & +++ & +++ & +++ & +++ & \\
\hline
\end{tabular}

1: Brain, 2: Nasal Cavity, 3: Trachea, 4: Feather, 5: Thymus, 6: Heart, 7: Lung, 8: Proventiculus, 9: Liver, 10: Spleen, 11: Intestine, 12: Pancreas, 13: Kidney, 14: Bursa

$-:$ No antigen, $+:$ Few (1-5 antigen/field), ++ : Moderate (6-10 antigens/field), +++ : Enormous (more than 10 antigens/field)
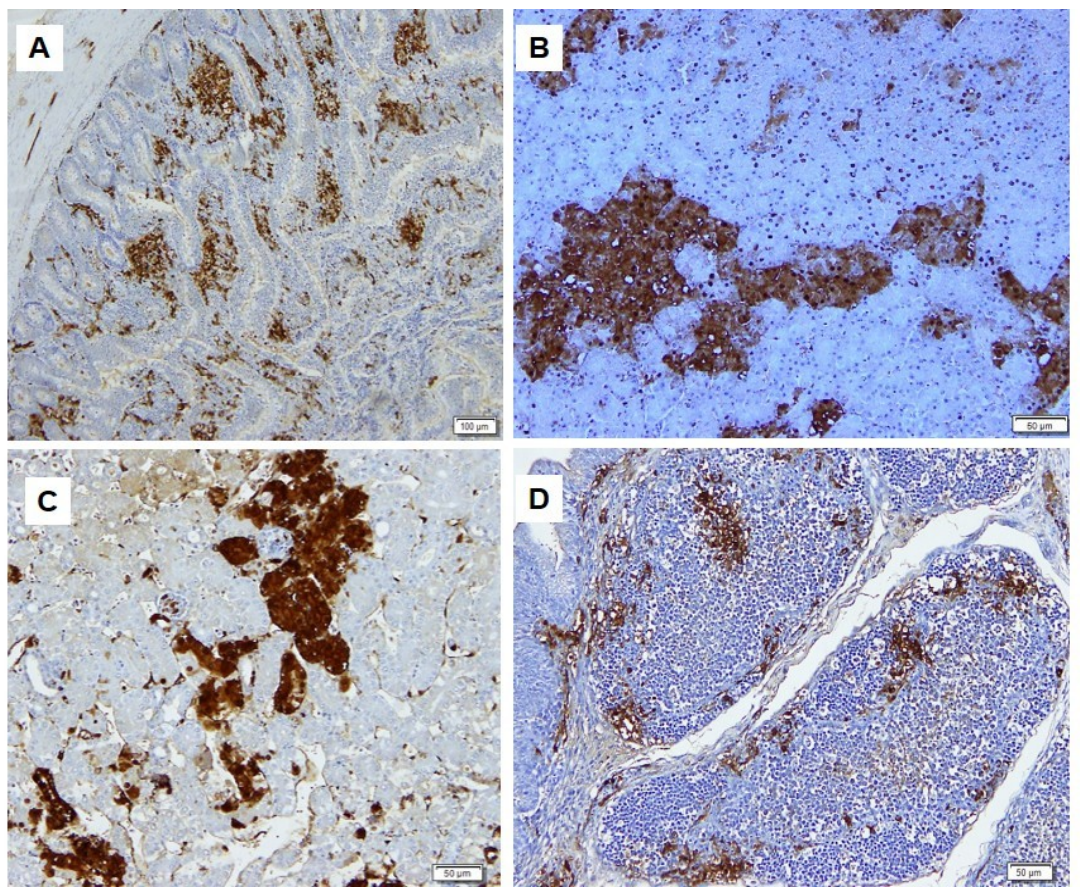

Figure 3. Antigen distribution in intestine (A), pancreas (B), kidney (C) and bursa Fabricius (D). Immunohistochemistry, DAB 
red pulps, tubular area of kidneys and follicular area of bursa fabricius. Mononuclear cellular infiltration was observed in the interstitial brain tissue, tracheal mucosa, interstitial lung, heart, liver, proventriculus, intestine, pancreas and kidney. The type of lesion was classified as non suppurative. Gliosis and demyelination were also found in the brain. Necrotizing spleen and pancreas were also prominent. Figure 2 presents some of the lesions. This findings were previously reported in the first HPAI outbreak in Indonesia (Damayanti, et al., 2004b) and other countries (Bröjer et al., 2015).

Antigen of $\mathrm{H} 5 \mathrm{~N} 1$ was detected in high intensity in various organs: skin, feather structure and feather follicle, infra orbital and intra nasal sinuses, trachea, brain, thymus, heart, lung, liver, spleen, intestine, pancreas, kidney and bursa fabricius as shown in Table 3. This finding reflected severe clinical signs and pathogenicity of the virus. Similar results were reported by Bröjer et al. (2009) whereby found in visceral organs associated with viral detection in the liver, lung, adrenal glands, kidneys, and peripheral nerve ganglia by immunohistochemistry. The viral antigen in feather structure and follicle is similar to previous studies of duck and chicken infected with H5N1 HPAI virus (Nuradji et al., 2015, Nuradji et al., 2016, Yamamoto et al., 2007).

\section{CONCLUSION}

The study shows that Indonesia H5N1 HPAI virus clade 2.3.2 is highly pathogenic for Indonesian indigenous chickens and ducks. The infected ducks can trasmit the virus to Indonesian indigenous chickens easily and generated high mortality. This suggest that ducks should not be reared with Indonesian indigenous chickens to prevent the spread of virus.

\section{ACKNOWLEDGMENTS}

This study was supported by The Indonesian Agency for Agriculture Research and Development and Indonesian Research Center for Veterinary Science. We thank Kusmaedi, Agus Winarsongko, Ani Purwani, Zulkifli, Abdul Qodir, Murniati and Yudi Mulyadi for technical assistance throughout the project.

\section{REFERENCES}

Bingham, J., D. J. Green, S. Lowther, J. Klippel,
S. Burggraaf, D.E. Anderson, H. Wibawa, D. M. Hoa, N.T. Long, P.P. Vu, D. Middleton and P. W. Daniels. 2009. Infection studies with two highly pathogenic avian influenza strains (Vietnamese and Indonesian) in Pekin ducks (Anas platyrhynchos), with particular reference to clinical disease, tissue tropism and viral shedding. Avian Pathol. 38: 267-278.

Bröjer, C., E. O. Agren, H. Uhlhorn, K. Bernodt, T. Mörner, D. S. Jansson, R. Mattsson, S. Zohari, P. Thorén, M. Berg and D. GavierWidén. 2009. Pathology of natural highly pathogenic avian influenza H5N1 infection in wild tufted ducks (Aythya fuligula). J. Vet. Diagnostic Investig. 21: 579-587.

Bröjer, C., E. O. Agren, H. Uhlhorn, K. Bernodt, T. Mörner, D. S. Jansson, R. Mattsson, S. Zohari, P. Thorén, M. Berg and D. GavierWidén. 2009. Pathology of natural highly pathogenic avian influenza H5N1 infection in wild tufted ducks (Aythya fuligula). J. Vet. Diagnostic Investig. 21: 579-587.

Bröjer, C., G. Van Amerongen, M. Van De Bildt, P. Van Run, A. Osterhaus, D. GavierWidén and T. Kuiken. 2015. Pathogenicity and tissue tropism of currently circulating highly pathogenic avian influenza A virus (H5N1; clade 2.3.2) in tufted ducks (Aythya fuligula). Vet. Microbiol. 180: 273-280.

Costa, T., A. J. Chaves, R. Valle, A. Darji, D. Van Riel, T. Kuiken, N. Majó and A. Ramis. 2012. Distribution patterns of influenza virus receptors and viral attachment patterns in the respiratory and intestinal tracts of seven avian species. Vet. Res. 43: 28.

Damayanti, R., N.L.P.I.. Dharmayanti, R. Indriani, A. Wiyono, and Darminto. 2004a. Deteksi Virus Avian Influenza Subtipe H5N1 pada Organ Ayam yang Terserang Flu Burung Sangat Patogenik di Jawa Timur dan Jawa Barat dengan Teknik Imunohistokimia. 9: 197-203.

Damayanti, R., N. L. P. I. Dharmayanti, A. Wiyono, R. Indriani, and Darminto. 2004b. Gambaran Klinis dan Patologis pada Ayam yang Terserang Flu Burung Sangat Patogenik (HPAI) di Beberapa Peternakan di Jawa Timur dan Jawa Barat. JITV 9: 128-135.

Dharmayanti, N. L. P. I., R. Hartawan, D. A. 
Hewajuli, Hardiman, H. Wibawa and Pudjiatmoko. 2013. Karakteristik molekuler dan patogenisitas virus $\mathrm{H} 5 \mathrm{~N} 1$ clade 2.3.2 asal Indonesia. JITV 18: 99113.

Drury, R.A.B. and E.A. Wallington. 1980. Carleton's Histological Technique. Oxford University. pp 36-56, 125-150

Hu, X., D. Liu, M. Wang, L. Yang, M. Wang, Q. Zhu, L. Li and G. F. Gao. 2011. Clade 2.3.2 Avian Influenza Virus (H5N1), Qinghai Lake Region, China, 2009-2010. Emerg. Infect. Dis. 17: 560-562.

Kang, H.M., D. Batchuluun, M.C. Kim, J.G. Choi, T.O. Erdene-Ochir, M.R. Paek, T. Sugir, R. Sodnomdarjaa, J.H. Kwon and Y. J. Lee. 2011. Genetic analyses of H5N1 avian influenza virus in Mongolia, 2009 and its relationship with those of eastern Asia. Vet. Microbiol. 147: 170-175.

Kim, H.R., B.S. Kim, Y.C. Bae, O.K. Moon, J.K. Oem, H.M. Kang, J.G. Choi, O.S. Lee and Y.J. Lee. 2011. H5N1 subtype highly pathogenic avian influenza virus isolated from healthy mallard captured in South Korea. Vet. Microbiol. 151: 386-389.

Marinova-Petkova, A., G. Georgiev, P. Seiler, D. Darnell, J. Franks, S. Krauss, R. J. Webby and R. G. Webster. 2012. Spread of influenza virus a $(\mathrm{H} 5 \mathrm{~N} 1)$ clade 2.3.2.1 to Bulgaria in common buzzards. Emerg. Infect. Dis. 18: 1596-1602.

Nagarajan, S., C. Tosh, D. K. Smith, J. S. M. Peiris, H. V. Murugkar, R. Sridevi, M. Kumar, M. Katare, R. Jain, Z. Syed, P. Behera, C. L. Cheung, R. Khandia, S. Tripathi, Y. Guan and S. C. Dubey. 2012. Avian Influenza (H5N1) Virus of Clade 2.3.2 in Domestic Poultry in India. PLoS One 7: e31844.

Nemeth, N. M., J. D. Brown, D. E. Stallknecht, E. W. Howerth, S. H. Newman and D. E. Swayne. 2013. Experimental infection of Bar-Headed Geese (Anser indicus) and Ruddy Shelducks (Tadorna ferruginea) with a Clade 2.3.2 H5N1 highly pathogenic Avian Influenza virus. Vet. Pathol. 50: 961-970.

Nuradji, H., J. Bingham, S. Lowther, H. Wibawa, A. Colling, N.T. Long and J. Meers. 2015. A comparative evaluation of feathers, oropharyngeal swabs, and cloacal swabs for the detection of H5N1 highly pathogenic avian influenza virus infection in experimentally infected chickens and ducks. J. Vet. Diagnostic Investig. 27: 704-715.

Nuradji, H., J. Bingham, J. Payne, J. Harper, S. Lowther, H. Wibawa, N.T. Long and J. Meers. 2016. Highly Pathogenic Avian Influenza (H5N1) Virus in Feathers: Tropism and Pathology of Virus-Infected Feathers of Infected Ducks and Chickens . Vet. Pathol. e0300985816666608.

OIE. 2012. Avian Influenza in OIE - World Organisation for Animal Health: Manual of Diagnostic Tests and Vaccines for Terrestrial Animals 2013. 436-454.

Pantin-Jackwood, M., D. E. Swayne, D. Smith, and E. Shepherd. 2013. Effect of species, breed and route of virus inoculation on the pathogenicity of $\mathrm{H} 5 \mathrm{~N} 1$ highly pathogenic influenza (HPAI) viruses in domestic ducks. Vet. Res. 44: 1-11.

Reid, S. M., W. Shell, G. Barboi, I. Onita, M. Turcitu, R. Cioranu, A. Marinova-Petkova, G. Goujgoulova, R.J. Webby, R.G. Webster, C. Russell, M.J. Slomka, A. Hanna, J. Banks, B. Alton, L. Barrass, R.M. Irvine and I.H. Brown. 2011. First reported incursion of highly pathogenic notifiable avian influenza A H5N1 viruses from clade 2.3.2 into European poultry. Transbound. Emerg. Dis. 58: 76-78.

Sartika, T, S Sulandari, Z.M. Syamsul. 2011. Selection of Mx gene genotype as genetic marker for Avian Influenza resistance in Indonesian native chicken. BMC Proc. 5(Suppl 4): S37

Shi, S. and C. Taylor. 2013. Antigen Retrieval in Education Guide-Immunohistochemical Staining Methods, edited by C. Taylor, L. Rudbeck, and A. Sjorup. Dako.30-42.

Swayne, D.E. and M. Pantin-Jackwood. 2006. Pathogenicity of avian influenza viruses in poultry. Dev Biol (Basel). 124:61-7.

Swayne, D.E. and M. Pantin-Jackwood. 2008. Pathobiology of influenza virus infections in birds and mammals, In: Swayne, D.E. (Ed.) Avian Influenza. Blackwell Publishing, Iowa, pp. 87-122.

Swayne, D. E. and D. A. Halvorson. 2008. Influenza in Diseases of Poultry (Y. M. Saif, A. M. Fadly, J. R. Glisson, L. R. McDougald and L. K. Nolan, eds). Blackwell Publishing Ltd, Iowa. P. 153184.

The International Committee on Taxonomy of 
Viruses. 2012. Virus Taxonomy Ninth Report of the International Committee on Taxonomy of Viruses.

Tong, S., Y. Li, P. Rivailler, C. Conrardy, D. A. A. Castillo, L. -M. Chen, S. Recuenco, J.A. Ellison, C.T. Davis, I.A. York, A.S. Turmelle, D. Moran, S. Rogers, M. Shi, Y. Tao, M.R. Weil, K. Tang, L.A. Rowe, S. Sammons, X. Xu, M. Frace, K.A. Lindblade, N.J. Cox, L.J. Anderson, C.E. Rupprecht and R.O. Donis. 2012. A distinct lineage of influenza A virus from bats. Proc. Natl. Acad. Sci. 109: 42694274.

Tong, S., X. Zhu, Y. Li, M. Shi, J. Zhang, M. Bourgeois, H. Yang, X. Chen, S. Recuenco, J. Gomez, L.-M. Chen, A. Johnson, Y. Tao, C. Dreyfus, W. Yu, R. McBride, P.J. Carney, A.T. Gilbert, J. Chang, Z. Guo, C.T. Davis, J.C. Paulson, J. Stevens, C.E. Rupprecht, E.C. Holmes, I.A. Wilson and R. Donis. 2013. New World Bats Harbor Diverse Influenza A Viruses. PLoS Pathog 9: e1003657.

Webster, R. G., and E. A. Govorkova, 2006 H5N1 influenza-continuing evolution and spread. New Engl J Med 355: 2174-2177.

Wibawa, H., W. B. Prijono, N. Dharmayanti, S. H. Irianingsih, Y. Miswati, A. Rohmah, E. Andesyha, D.R.S.D. Romlah and K. Safitria. 2012. Investigasi wabah penyakit pada itik di Jawa Tengah, Yogyakarta dan Jawa Timur: Identifikasi sebuah clade baru virus avian influenza subtipe $\mathrm{H} 5 \mathrm{~N} 1 \mathrm{di}$ Indonesia. Bul. Lab. Veteriner. Balai Besar Vet. Wates Jogjakarta 12: 2-8.

Wibawa, H., J. Bingham, H. Nuradji, S. Lowther,
J. Payne, J. Harper, F. Wong, R. Lunt, A. Junaidi, and D. Middleton. 2013. The pathobiology of two Indonesian H5N1 avian influenza viruses representing different clade 2.1 sublineages in chickens and ducks. Comp. Immunol. Microbiol. Infect. Dis. 36, 175-191.

Wiyono, A., R. Indriani, N. Dharmayanti, R. Damayanti, L. Parede and T. Syafriati. 2004. Isolasi Dan Karakterisasi Virus Highly Pathogenic Avian Influenza Subtipe H5 Dari Ayam Asal Wabah Di Indonesia (Isolation And Characterization Of Virus Of Highly Pathogenic Avian Influenza H5 Subtype Of Chicken From Outbreaks In Indonesia). JITV 9: 2004.

Xu, X., K. Subbarao, N. J. Cox and Y. Guo. 1999. Genetic Characterization of the Pathogenic Influenza A/Goose/Guangdong/1/96 (H5N1) Virus: Similarity of Its Hemagglutinin Gene to Those of H5N1 Viruses from the 1997 Outbreaks in Hong Kong. Virology 261, 15-19.

Yamamoto, Y., K. Nakamura, K. Kitagawa, N. Ikenaga, M. Yamada, M. Mase and M. Narita. 2007. Severe nonpurulent encephalitis with mortality and feather lesions in call ducks (Anas platyrhyncha var. domestica) inoculated intravenously with H5N1 highly pathogenic avian influenza virus. Avian Dis. 51: 52-57

Zhao, G., L. Zhong, X. Lu, J. Hu, X. Gu, Y. Kai, Q. Song, Q. Sun, J. Liu, D. Peng, X. Wang and X. Liu. 2012. Characterisation of a highly pathogenic $\mathrm{H} 5 \mathrm{~N} 1$ clade 2.3.2 influenza virus isolated from swans in Shanghai, China. Virus Genes 44: 55-62. 